\title{
DISPARITAS PIDANA DALAM PUTUSAN HAKIM TERHADAP TINDAK PIDANA PSIKOTROPIKA DI PENGADILAN NEGERI SLEMAN
}

\author{
Kurnia Dewi Anggraeny \\ Fakultas Hukum Universitas Ahmad Dahlan \\ Dosen Hukum Pidana \\ Email: kurniadewi@law.uad.ac.id
}

\begin{abstract}
ABSTRAK
Penelitian tentang disparitas pidana dalam putusan hakim terhadap tindak pidana psikotropika di Pengadilan Negeri Sleman ini menunjukkan bahwa di dalam praktik disparitas pidana dalam pengenaan sanksi pidana terhadap pelaku tindak pidana psikotropika memang terjadi. Penyebab terjadinya disparitas pidana terhadap tindak pidana psikotropika bersumber pada berbagai hal yakni: dari diri hakim, dari hukumnya sendiri, serta karakteristik kasus yang bersangkutan. Upaya meminimalisir disparitas pidana dapat dilakukan dengan mengefektifkan fungsi majelis hakim dengan menggunakan semua potensi yang ada pada diri hakim sendiri atau dapat dilakukan dengan mengadakan pelatihan yang diikuti oleh semua subsistem peradilan pidana agar memiliki persamaan visi dan misi terhadap peradilan pidana. Selain itu dapat digunakan suatu pendekatan dengan menciptakan pedoman pemberian pidana, meningkatkan peranan pengadilan banding, seleksi dan latihan para hakim, khususnya di Pengadilan Negeri untuk konsistensi kebijakan pemidanaan.
\end{abstract}

Kata Kunci: Disparitas, Psikotropika, Kriminal, Sanksi

\section{ABSTRACT}

This research studies about the sentencing disparity of judge decisions on psychotropic criminal offences in Sleman District Court. This research proves that sentencing disparity in psychotropic criminal offences does occur. The existence of sentencing disparity is caused by some factors: the judges themselves, the law, and the characteristic of the case involved. The effort to reduce sentencing disparity can be done by behaving the function of judges effectively using all of the judge's selfpotential. Besides it can also be done by organizing training for all the criminal justice subsystems to have same vision and mission over criminal justice. In another way, it can also be done by using an approach through formulating the instruction in sentencing, improving the role of the appeal court, selecting and training the judges, in particular for the consistency of penalization policy in the District Court.

Keywords: Disparity, Psychotropic, Criminal, Sanction 


\section{A. LATAR BELAKANG}

Sistem peradilan pidana adalah sistem suatu masyarakat untuk menanggulangi masalah kejahatan. Menanggulangi di sini berarti usaha untuk mengendalikan kejahatan agar berada pada batas-batas toleransi masyarakat (Reksodiputro: 2007, 84). Sistem peradilan pidana sangat dipengaruhi oleh lingkungan masyarakat dan bidang kehidupan manusia. Oleh karena itu dalam geraknya akan selalu mengalami interaksi, interkoneksi, dan interdependensi dengan lingkungannya serta sub-sub sistem dari sistem peradilan pidana itu sendiri (Arif, 2011: 15). Sistem ini terdiri atas sub-sub sistem pendukungnya, yaitu kepolisian, kejaksaan, pengadilan dan lembaga pemasyarakatan yang secara keseluruhan merupakan satu kesatuan yang berusaha mentransformasikan masukan (input) dan menjadi keluaran (output) untuk mencapai tujuan Sistem peradilan pidana yaitu resosialisasi pelaku tindak pidana (jangka pendek), pencegahan kejahatan (jangka menengah), dan kesejahteraan sosial (jangka panjang). Sebagai suatu sarana untuk menanggulangi masalah tindak pidana, sistem peradilan pidana sangat diharapkan mampu bekerja secara efektif dan efisien.

Lembaga peradilan sebagai lembaga penegakan hukum dalam sistem peradilan pidana (Criminal Justice System) merupakan suatu tumpuan harapan dari para pencari keadilan. Keadilan yang hakiki merupakan suatu syarat yang utama untuk mempertahankan kelangsungan hidup suatu masyarakat, dalam hal hakim mempunyai suatu peranan penting dalam penegakan hukum pidana untuk tercapainya suatu keadilan yang diharapkan dan dicita-citakan (Anwar dan Adang, 2009: 218). Nilai suatu keadilan di dalam masyarakat mempunyai persepsi atau pemikiran yang berbeda dengan arti keadilan bagi hakim yang secara langsung menangani setiap perkara di pengadilan, seperti yang disampaikan oleh Sudikno Mertokusumo (Mertokosumo dan A. Pitlo, 2013: 2):

"Eksistensi hakim sebagai alat penegak hukum di Indonesia dewasa ini mempunyai suatu persepsi yang negatif dari masyarakat, hal tersebut dikarenakan banyak sekali putusan masyarakat. Disamping itu juga karena semakin komleksnya bentuk dari kejahatan yang terjadi yang belum ada pengaturannya di dalam undang-undang hukum pidana sehingga apa yang menjadi tujuan hukum pidana tidak tercapai dengan ruang lingkup sistem peradilan hukum."

Putusan hakim di Indonesia atas suatu kasus menjadi sesuatu yang ditunggu karena dimungkinkan terjadi penjatuhan pidana yang berbeda meskipun tindak pidananya sama. Perbedaan putusan hakim yang dimaksud dikarenakan adanya kebebasan hakim yang didasarkan pada kemandirian dan kekuasaan kehakiman yang telah dijamin dalam Undang-Undang Dasar 1945 dan diimplementasikan dalam Undang-Undang Nomor 14 Tahun 1970 tentang Pokok-Pokok Kekuasaan Kehakiman dan perubahannya kepada Undang-Undang Nomor 4 Tahun 2004. Akan tetapi walaupun demikian tidaklah boleh hakim menyalahgunakan kedudukannya yang bebas itu. Terkait dengan hal tersebut Sudarto menyatakan bahwa (Sudarto, 2007: 61): 
"Kebebasan hakim dalam menetapkan pidana tidak boleh sedemikian rupa, sehingga memungkinkan terjadinya ketidaksamaan yang menyolok, di mana akan mendatangkan perasaan tidak sreg (onbehagelijk) bagi masyarakat, maka pedoman memberikan pidana dalam KUHP sangat diperlukan, sebab ini akan mengurangi ketidaksamaan tersebut meskipun tidak dapat menghapuskannya sama sekali."

Selain itu dianutnya sistem pidana minimal umum, maksimal umum, dan maksimal khusus (untuk masing-masing tindak pidana) juga membuka peluang bagi hakim untuk menggunakan kebebasannya dalam menjatuhkan pidana. Tidak adanya pedoman pemberian pidana yang umum dalam KUHP yang berlaku sekarang dipandang pula sebagai dasar hakim untuk bebas menjatuhkan putusannya.

Masalah yang kemudian muncul sebagai dampak dari kondisi-kondisi tersebut adalah disparitas pidana, yaitu perbedaan putusan hakim terhadap tindak pidana sejenis, baik putusan yang dijatuhkan oleh satu majelis hakim atau majelis hakim yang berbeda. Undang-undang pidana yang baik diharapkan dapat sejalan dengan tuntutan perkembangan sosial yang bisa dipandang sebagai sarana untuk melakukan tindakan prevensi umum (Makarao, 2003: 14).

Keberadaan Undang-Undang Psikotropika merupakan suatu upaya (politik hukum pemerintah Indonesia) terhadap penanggulangan tindak pidana psikotropika. Dengan demikian, diharapkan dengan dirumuskanya undang-undang tersebut dapat menanggulangi peredaran gelap dan penyalahgunaan psikotropika, serta menjadi acuan dan pedoman kepada pengadilan dan para penyelenggara atau pelaksana putusan pengadilan yang menerapkan undang-undang, khususnya hakim dalam menjatuhkan sanksi pidana terhadap kejahatan yang terjadi.

Menurut Drs. Ahmad Alamsyah, Kepala Bidang Pencegahan BNN (Badan Narkotika Nasional), jumlah kasus pengguna narkotika, psikotropika dan bahan adiktif (narkoba) di Indonesia tiap tahun selalu mengalami peningkatan dengan beberapa fakta kasus yang ditemukan. Sehingga semakin banyak pelaku penyalahgunaan psikotropika yang terjerat Undang-Undang Nomor 5 Tahun 1997 dan putusan yang dijatuhkan oleh hakim tentang tindak pidana psikotropika semakin beragam.

Pendapat masyarakat awam seringkali menilai suatu perbuatan yang dilakukan oleh seseorang dengan orang lain, bisa saja berbeda alasan atau motif dalam melakukan perbuatan pidana meskipun perbuatan itu sama. Tidak jarang terjadi perbedaan sanksi pidana yang dijatuhkan kepada seseorang dan orang lain yang melakukan suatu perbuatan pidana yang sama atau sejenis. Contohnya adalah kasus psikotropika, posisi seseorang pengguna psikotropika dengan pengguna lainnya bisa berbeda penjatuhan sanksi pidananya.

Perbedaan atau disparitas pidana psikotropika adalah perbedaan hukuman atau sanksi pidana yang dijatuhkan oleh hakim kepada pelaku tindak pidana narkotika antara satu dengan yang lainnya dengan menggunakan dasar pasal yang sama atau perbedaan barang bukti yang tidak begitu mencolok. Adapula sanksi 
pidana yang dijatuhkan sama tetapi dengan barang bukti yang jauh berbeda jumlahnya.

Disparitas pidana mempunyai dampak yang dalam karena di dalamnya terkandung pertimbangan konstitusional antara kebebasan individu dan hak negara untuk menjatuhkan pidana. Pidana sendiri dalam hal ini harus diartikan sebagai pengenaan penderitaan yang dilakukan dengan sengaja oleh orang atau lembaga yang mempunyai kekuasaan atau wewenang terhadap seseorang yang telah melakukan tindak pidana menurut undang-undang.

Disparitas pidana akan berakibat fatal, apabila dikaitkan dengan catatan atau administrasi hasil persidangan. Terpidana yang membandingkan pidananya dengan terpidana yang lain dan merasa ada disparitas pidana, maka ia akan memandang dirinya sebagai korban ketidakadilan (Muladi dan Arief, 2005: 54). Selanjutnya yang bersangkutan akan sulit dimasyarakatkan dan bahkan tidak menghargai hukum, padahal penghargaan terhadap hukum tersebut merupakan salah satu target di dalam tujuan pemidanaan. Dari sini akan tampak suatu persoalan yang serius, sebab akan menjadi indikator dan manifestasi dari kegagalan suatu sistem untuk mencapai persamaan keadilan di dalam negara hukum, sekaligus akan melemahkan kepercayaan masyarakat terhadap sistem penyelenggaraan hukum pidana.

Adanya fenomena disparitas pidana dalam penegakan hukum oleh hakim terhadap tindak pidana psikotropika merupakan suatu hal yang menarik bagi penulis sebagai pembahasan dalam penelitian dengan cakupan spesifik di Kabupaten Sleman. Pertanyaan yang terumuskan adalah:

1. Mengapa terjadi disparitas pidana dalam putusan hakim terhadap Tindak Pidana Psikotropika di Pengadilan Negeri Sleman?

2. Upaya apa yang dapat dilakukan untuk meminimalisir terjadinya disparitas pidana terhadap tindak pidana psikotropika?

\section{B. METODE PENELITIAN}

Penelitian ini secara spesifik adalah penelitian hukum yurisprudensi. Objek yang menjadi kajian dalam penelitian ini adalah Disparitas Pidana Dalam Putusan Hakim Terhadap Tindak Pidana Psikotropika Di Pengadilan Negeri Sleman. Beberapa sumber dalam penelitian ini meliputi putusan-putusan kasus tindak pidana psikotropika di Pengadilan Negeri Sleman dan melalui wawancara hakim yang pernah menjatuhkan putusan terhadap kasus tindak pidana psikotropika di Pengadilan Negeri Sleman.

Kajian ini menggunakan model deskriptif kualitatif melalui pendekatan yuridis sosiologis dengan menjelaskan perbedaan penjatuhan sanksi pidana terhadap pelaku tindak pidana psikotropika di Pengadilan Negeri Sleman. Pendekatan yuridis dilakukan untuk mengkaji keterkaitan antara peraturan perundang-undangan dengan keputusan hakim. Sedangkan pendekatan sosiologis digunakan untuk melihat bagaimana peraturan perundang-undangan yang diterapkan dalam praktik peradilan, pendekatan sosiologis inipun juga diperlukan 
untuk mendapatkan jawaban tentang terjadinya perbedaan putusan pidana terhadap pelaku penyalahgunaan psikotropika.

Data-data hukum melalui metode pendekatan yuridis normatif dilakukan dengan:

1. Studi Pustaka/Literatur adalah pengkajian informasi tertulis mengenai hukum yang berasal dari berbagai sumber dan dipublikasikan secara luas, yakni dengan mengkaji karangan-karangan ilmiah, literatur, putusan pengadilan yang berhubungan dengan kasus psikotropika.

2. Studi Dokumen adalah pengkajian informasi tertulis mengenai hukum yang tidak dipublikasikan secara umum tetapi boleh diketahui oleh pihak tertentu seperti pengajar hukum, peneliti hukum, praktisi hukum dalam rangka kajian hukum, pengembangan hukum serta praktik hukum, adapun sumbernya adalah berbagai dokumen resmi institusional yang berupa peraturan, UndangUndang Nomor 5 Tahun 1997 tentang Psikotropika, laporan penelitian hukum dan dokumen lain yang berhubungan dengan permasalahan penelitian.

Sementara data-data tersebut dikumpulkan dengan cara:

1. Mengambil sampel / data yang dibutuhkan yaitu berkas putusan hakim di Pengadilan Negeri Sleman mengenai kasus Psikotropika merujuk pada Pasal 62 dan Pasal 60 ayat (5) Undang-Undang Nomor 5 Tahun 1997.

2. Wawancara dengan nara sumber yaitu beberapa hakim di Pengadilan Negeri Sleman.

Data yang terkumpul dari hasil penelitian ini dianalisa secara deskriptif kualitatif dengan mencari dan menyusun secara sistematis data yang diperoleh dari hasil wawancara, catatan lapangan, dan dokumentasi. Penyusunan dilakukan dengan mengorganisasikan data ke dalam kategori, menjabarkan ke dalam unit-unit, melakukan sintesa, menyusun ke dalam pola, dan membuat kesimpulan (Emadila, Zulfita, dan Ahmad: 2014, 4).

\section{PEMBAHASAN}

\section{Disparitas Pidana}

Menurut Harkristuti Harkrisnowo, disparitas pidana dapat terjadi dalam beberapa kategori yaitu (Harkrisnowo, 2003: 77):

a. Disparitas antara tindak pidana yang sama

b. Disparitas antara tindak pidana yang mempunyai tingkat keseriusan yang sama

c. Disparitas pidana yang dijatuhkan oleh satu majelis hakim

d. Disparitas antara pidana yang dijatuhkan oleh majelis hakim yang berbeda untuk tindak pidana yang sama

Dari pendapat Harkristuti Harkrisnowo tersebut ditemukan wadah di mana disparitas tumbuh dan mempunyai sejarah dalam penegakan hukum di Indonesia. Disparitas tidak hanya terjadi pada tindak pidana yang sama, tetapi juga pada tingkat keseriusan dari suatu tindak pidana, dan juga dari putusan hakim, baik satu majelis hakim maupun oleh majelis hakim yang berbeda untuk perkara yang sama. 
Tentu saja kenyataan mengenai ruang lingkup tumbuhnya disparitas ini menimbulkan inkonsistensi di lingkungan peradilan.

Penulis berpandangan bahwa konsep tentang disparitas pidana yang dikemukakan oleh Harkristuti Harkrisnowo tersebut dilandasi pula oleh konsep disparitas pidana yang mengacu pada pendapat Muladi dan Barda Nawawi berikut ini (Rahayu, 2005: 44):

"Muladi dan Barda Nawawi Arief tidak memberikan batasan disparitas pidana yang diperbolehkan atau tidak, namun putusan hakim seharusnya mengandung keseimbangan pemidanaan yang didasarkan pada pertimbangan yang serasi. Serasi dengan keputusan-keputusan yang sudah ada, serasi dengan keputusan-keputusan hakim lain dalam perkara yang sejenis, serasi dengan keadilan masyarakat dan serasi pula dengan keadilan terpidana."

Menurut Muladi, disparitas pidana itu dimulai dari hukum itu sendiri (Muladi dan Arief, 2005: 56). Pada hukum positif Indonesia, hakim mempunyai kebebasan yang sangat luas untuk memilih jenis pidana (strafsort) yang dikehendaki sehubungan dengan penggunaan sistem alternatif di dalam pengancaman pidana dalam Undang-Undang. Contoh sistem alternatif dapat dilihat dari ketentuan Pasal 188 KUHP, yang bunyinya adalah sebagai berikut:

"Barang siapa karena kesalahan (kealpaan) menyebabkan kebakaran, ledakan atau banjir, diancam dengan pidana penjara paling lama lima tahun atau pidana kurungan paling lama satu tahun atau pidana denda paling banyak empat ribu lima ratus rupiah, jika karena perbuatan itu timbul bahaya umum bagi barang, jika karena perbuatan itu timbul bahaya bagi nyawa orang lain, atau jika karena perbuatan itu mengakibatkan orang mati."

Dari ketentuan pasal tersebut dapat dilihat adanya beberapa pidana pokok yang diancamkan terhadap pelaku tindak pidana yang sama secara alternatif. Di antara beberapa aturan hukum yang ada diberikan yang paling tepat untuk dapat diterapkan pada pelaku tindak pidana. Di samping itu hakim juga bebas untuk memilih beratnya pidana (strafmaat) yang akan dijatuhkan, karena yang ditentukan oleh undang-undang hanyalah maksimum dan minimumnya saja.

Muladi juga menyatakan bahwa di samping hal-hal yang bersumber pada hukum, ada hal-hal lain yang menyebabkan terjadinya disparitas pidana. Hal-hal yang dimaksud adalah faktor-faktor yang bersumber dari diri hakim sendiri, baik yang bersifat internal maupun eksternal yang tidak bisa dipisahkan karena sudah terpaku sebagai atribut seseorang yang disebut sebagai human equation (insan peradilan) atau personality of judge dalam arti luas yang menyangkut pengaruhpengaruh latar belakang sosial, pendidikan agama, pengalaman dan perilaku sosial (Muladi dan Arief, 2005: 58). Hal-hal itulah yang seringkali memegang peranan penting di dalam menentukan jenis dan beratnya hukuman daripada sifat perbuatannya sendiri dan kepribadian dari pelaku tindak pidana yang bersangkutan.

Seorang hakim yang memandang bahwa aliran klasik lebih baik daripada aliran modern akan memidana lebih berat sebab ia beranggapan bahwa pidana itu 
harus disesuaikan dengan kejahatan (Muladi dan Arief, 2005: 59). Jadi yang menjadi sorotan di sini adalah kejahatan itu sendiri. Sebaliknya hakim yang berpandangan modern akan memidana lebih ringan sebab orientasinya bukan lagi kejahatan tetapi kepada si penjahat itu sendiri. Jadi pemidanaan harus sesuai dengan penjahat.

Dengan adanya aliran modern tersebut dapat menghasilkan penemuanpenemuan ilmu sosial dan ilmu-ilmu alam yang mempelajari tentang perbuatan seseorang. Sehingga dapat digunakan untuk menunjang usaha pembinaan narapidana berdasarkan filsafat individualistik, oleh karena beberapa hal tersebut faktor-faktor penyebab disparitas pidana semakin bervariasi. Hal ini disebabkan karena diakui adanya keadaan tertentu, baik fisik, mental, maupun lingkungan sebagai keadaan keadaan yang meringankan (Muladi dan Arief, 2005: 60).

\section{Kasus Tindak Pidana Psikotropika}

\section{a. Perkara Pidana Pasal 62 Undang-Undang Nomor 5 Tahun 1997}

Merujuk kepada Pasal 62, ketika seseorang melakukan perbuatan penyalahgunaan psikotropika sebagaimana diatur dalam Pasal 62 pastilah yang bersangkutan telah memenuhi unsur-unsur yang terdapat di dalam pasal tersebut. Salah satu unsur dari Pasal 62 ini adalah "Secara tanpa hak memiliki, menyimpan dan/atau membawa psikotropika". Unsur ini adalah unsur alternatif sehingga apabila salah satu dari unsur tersebut telah dapat dibuktikan maka unsur yang lainnya tidak perlu dibuktikan lagi.

Tindak pidana dalam Pasal 62 sendiri termasuk dalam kejahatan yang menyangkut penguasaan psikotropika. Kata penguasaan di sini diartikan dengan memiliki, menyimpan, atau membawa. Seperti telah disebutkan di atas pengertian dari "penguasaan" tersebut adalah bersifat alternatif.

Pada kasus psikotropika yang telah putus pemidanaannya di Pengadilan Negeri Sleman terdapat putusan pidana yang nyaris sama dengan barang bukti yang berbeda. Perkara tersebut teregister dengan nomor perkara 20/Pid. B/2008/PN.SLMN (dengan pidana 10 bulan penjara) dan nomor perkara 60/Pid. B/2008/PN.SLMN (dengan pidana penjara 9 bulan penjara). Pada perkara pertama didapati barang bukti 1 (satu) paket shabu-shabu seberat 0,034 gram. Sementara perkara kedua ditemui barang bukti 1 (satu) paket shabu-shabu seberat 0,079 gram. Perbedaan itu menjadi menonjol manakala tidak ada pedoman putusan yang jelas untuk penjatuhan pidana yang disesuaikan dengan ukuran barang bukti.

\begin{tabular}{|c|l|c|l|}
\hline No. Perkara & \multicolumn{1}{|c|}{$\begin{array}{c}\text { Barang Bukti } \\
\text { dan Motif Pelaku }\end{array}$} & Pemidanaan & \multicolumn{1}{|c|}{ Keterangan } \\
\hline 20 / Pid. B / & $\begin{array}{l}\text { 1 paket shabu-shabu } \\
\text { seberat 0,034 gram }\end{array}$ & 10 bulan & $\begin{array}{l}\text { Perbedaan penjatuhan } \\
\text { pidana pada kasus ini } \\
\text { dapat terlihat } \\
\text { menonjol manakala } \\
\text { tidak ada pedoman } \\
\text { putusan yang jelas } \\
\text { untuk paket shabu-shabu } \\
\text { 1 Pid. B / } \\
\text { seberat 0,079 gram } \\
\text { pidana yanan } \\
\text { disesuaikan dengan }\end{array}$ \\
\hline
\end{tabular}




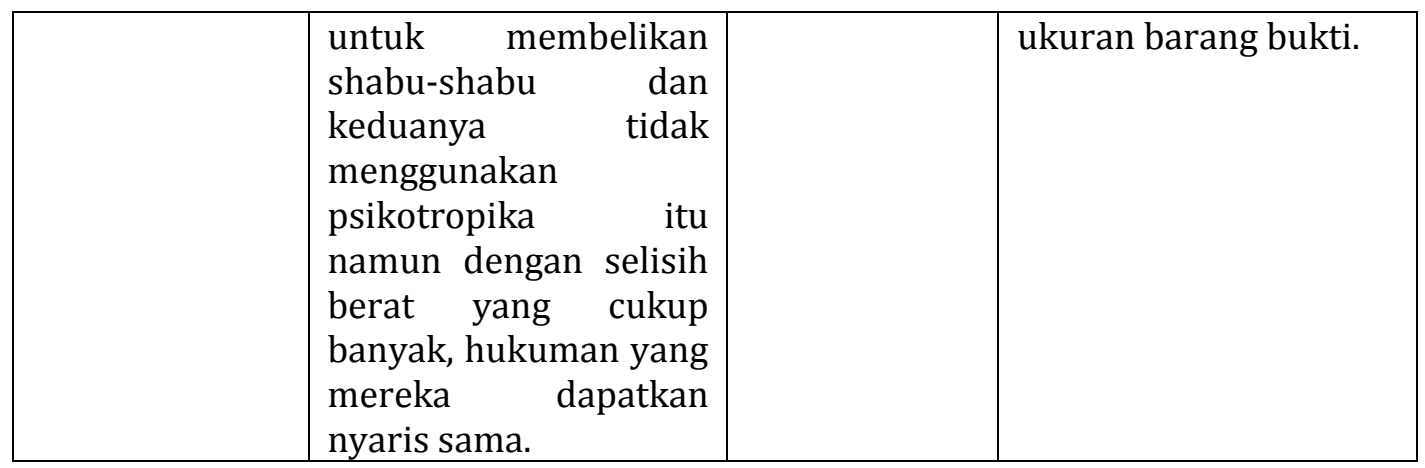

Tabel 1. Perkara Pidana Pasal 62 Undang-Undang Nomor 5 Tahun 1997

\section{b. Perkara Pidana Pasal 60 ayat (5) Undang-Undang Nomor 5 Tahun 1997}

Berkaitan dengan pasal ini, terdapat seseorang yang telah memenuhi unsurunsur penyalahgunaan psikotropika yang terdapat di dalam pasal tersebut. Salah satu unsur dari Pasal 60 ayat (5) ini adalah "Barangsiapa menerima penyerahan psikotropika selain yang ditetapkan dalam Pasal 14 ayat (13) dan Pasal 14 ayat (4)".

Terdapat perbedaan putusan antara nomor perkara 421/Pid. B/2009/PN.SLMN (pidana 1 bulan 15 hari penjara) dengan nomor perkara 492/Pid. B/2009/PN.SLMN (pidana penjara 4 bulan penjara). Motif para terdakwa samasama menerima psikotropika berupa pil riklona clonazepam dari orang lain, namun putusan keduanya mengalami perbedaan. Padahal putusan dengan pidana penjara 1 (satu) bulan 15 (lima belas) hari, sebelum dilakukan penangkapan terdakwanya telah mengkonsumsi pil riklona clonazepam tersebut. Selisih putusan pidana kurang lebih 3 (tiga) bulan itu akan tetap dirasakan tidak adil oleh terdakwa.

\begin{tabular}{|c|c|c|c|}
\hline No. Perkara & $\begin{array}{c}\text { Barang Bukti } \\
\text { dan Motif Pelaku }\end{array}$ & Pemidanaan & Keterangan \\
\hline $\begin{array}{c}421 \text { / Pid. B / } \\
2009\end{array}$ & $\begin{array}{l}4 \text { butir pil riklona } \\
\text { clonazepam } \\
10 \text { butir pil riklona } \\
\text { clonazepam } \\
\text { Masing-masing } \\
\text { terdakwa sama- } \\
\text { sama menerima } \\
\text { psikotropika } \\
\text { berupa pil riklona } \\
\text { clonazepam dari } \\
\text { orang lain. }\end{array}$ & $\begin{array}{l}1 \text { bulan, } \\
15 \text { hari } \\
4 \text { bulan }\end{array}$ & $\begin{array}{l}\text { Jika dilihat pada putusan } \\
\text { pada no. perkara } 421 \text { / } \\
\text { Pid. B / 2009, sebelum } \\
\text { dilakukan penangkapan } \\
\text { terdakwanya telah } \\
\text { mengkonsumsi pil } \\
\text { riklona clonazepam } \\
\text { tersebut. Selisih putusan } \\
\text { pidana kurang lebih } 3 \\
\text { (tiga) bulan itu akan } \\
\text { dirasakan tidak adil oleh } \\
\text { terdakwa. }\end{array}$ \\
\hline
\end{tabular}

Tabel 2. Perkara Pidana Pasal 60 ayat (5) Undang-Undang Nomor 5 Tahun 1997

Deskripsi disparitas pidana pada pelanggaran pasal 60 ayat (5) dan Pasal 62 Undang-Undang Nomor 5 Tahun 1997 hampir sama, yaitu perbedaan jumlah barang 
bukti psikotropika. Selisih berat atau ukuran barang bukti mempunyai dampak yang signifikan sebagai penyebab adanya perbedaan dalam penjatuhan putusan oleh hakim.

Kesimpulan yang dapat diambil penulis berkaitan dengan pelanggaran Pasal 62 dan Pasal 60 ayat (5) Undang-Undang Nomor 5 Tahun 1997 diperkuat oleh pendapat dari Erna Indrawati, salah satu hakim di Pengadilan Negeri Sleman yang juga sering memutus pada kasus penyalahgunaan psikotropika, di mana pada pokoknya menyatakan bahwa banyak sedikitnya jumlah barang bukti ternyata berpengaruh signifikan terhadap pidana yang akan dijatuhkan. Alasan itulah yang kemudian menjawab pertanyaan kenapa di Pengadilan Negeri Sleman putusan yang dijatuhkan sering mengalami disparitas pidana pada kasus penyalahgunaan psikotropika dan hakim jarang yang memberikan pidana maksimal atau mendekati maksimal pada pelakunya. (Wawancara dengan Erna Indrawati, Hakim di Pengadilan Negeri Sleman Yogyakarta, 4 Oktober 2012)

Namun yang perlu diperhatikan pada peraturan penyalahgunaan psikotropika adalah perlunya pedoman putusan yang jelas untuk penjatuhan pidana yang disesuaikan dengan ukuran barang bukti dan pedoman putusan untuk mengukur berat ringannya putusan pidana yang disesuaikan dengan motif terdakwa dalam melakukan penyalahgunaan psikotropika.

\section{Faktor-Faktor Penyebab Disparitas Pidana}

Disparitas pidana dapat disebabkan oleh beberapa faktor. Pertama, disparitas pidana dimulai dari hukum itu sendiri. Pada hukum pidana positif Indonesia, hakim mempunyai kebebasan yang sangat luas untuk memilih jenis pidana (strafsoort) yang dikehendaki, sehubungan dengan penggunaan sistem alternatif di dalam pengancaman pidana dalam undang-undang. Sebagai contoh adalah perumusan Pasal 188 KUHP yang berbunyi sebagai berikut:

"Barang siapa karena kealpaannya menyebabkan kebakaran, ledakan atau banjir, diancam dengan pidana penjara paling lama lima tahun atau kurungan paling lama satu tahun atau denda paling banyak tiga ratus rupiah, jika karenanya timbul bahaya bagi nyawa orang lain, atau jika karenanya diakibatkan matinya orang."

Dari bunyi pasal tersebut tampak bahwa beberapa pidana pokok seringkali diancamkan kepada pelaku perbuatan pidana yang sama secara alternatif, artinya satu di antara pidana pokok yang diancamkan tersebut dapat dijatuhkan hakim dan hal ini diserahkan kepadanya untuk memilih sendiri manakah yang paling tepat. Selain itu hakim juga mempunyai kebebasan untuk memilih beratnya pidana (strafmaat) yang akan dijatuhkan, sebab yang ditentukan oleh perundang-undangan hanyalah maksimum dan minimumnya.

Sehubungan dengan hal tersebut di atas, Sudarto menyatakan sebagai berikut: "KUHP Indonesia tidak memuat pedoman pemberian pidana (straftoemetingsleiddraad) yang umum, ialah suatu pedoman yang dibuat oleh pembentuk undang-undang yang memuat asas-asas yang perlu diperhatikan 
oleh Hakim dalam menjatuhkan pidana yang ada hanya aturan pemberian pidana (straftoemetingsregels)."

Faktor ini, pada sisi lain, juga mengandung kelemahan-kelemahan yang berhubungan dengan adanya perbedaan penjatuhan pidana oleh hakim yang terlalu luas karena tidak adanya pedoman aturan yang jelas (Muladi dan Arief, 2005: 58). Hal tersebut sering berperan penting dalam menentukan jenis dan beratnya pidana, daripada sifat perbuatan pidananya sendiri dan kepribadian pelaku tindak pidana yang bersangkutan.

Kedua, tentang besar kecilnya ukuran barang bukti yang saat itu ditemukan dalam penggeledahan atau penangkapan. Selain itu, hakim turut mempertimbangkan dari cara penemuan barang bukti tersebut, apakah penemuannya saat tertangkap tangan atau ditemukan melalui pencarian terlebih dahulu.

Ketiga, menyangkut motif/niat dari terdakwa dalam melakukan kejahatan. Selanjutnya dihubungkan dengan tujuan atau hasil akhir dari kejahatan yang telah terdakwa lakukan.

Menyangkut disparitas pidana, hal terpenting adalah sampai sejauh manakah disparitas pidana tersebut bersandar pada alasan penjatuhan pidana.

\section{Upaya Meminimalisir Terjadinya Disparitas Pidana}

Upaya untuk meminimalisir terjadinya disparitas pidnaa dapat dilakukan dengan mengefektifkan fungsi majelis hakim dengan menggunakan semua potensi yang ada di diri hakim sendiri, selain itu juga dapat dilakukan dengan mengadakan pelatihan dan seminar yang diikuti oleh semua subsistem peradilan pidana agar memiliki persamaan visi dan misi terhadap peradilan pidana.

Demikian pula dapat menggunakan pendekatan untuk memperkecil disparitas (approach to minimize disparity) dengan menciptakan pedoman pemberian pidana, meningkatkan peranan pengadilan banding, seleksi dan latihan para hakim khususnya di Pengadilan Negeri untuk konsistensi kebijakan pemidanaan. Hal ini memberikan kemungkinan bagi hakim untuk memperhitungkan seluruh kejadian yaitu dengan berat ringannya delik dan cara delik itu dilakukan. Selain itu pula diperlukan pedoman putusan yang jelas untuk penjatuhan pidana yang disesuaikan dengan ukuran barang bukti dan pedoman putusan untuk mengukur berat ringannya putusan pidana yang disesuaikan dengan motif terdakwa dalam melakukan penyalahgunaan psikotropika.

\section{KESIMPULAN DAN SARAN}

\section{Kesimpulan}

Dari hasil analisis pembahasan, dapat ditarik kesimpulan sebagai berikut:

a. Penyebab terjadinya disparitas pidana dipengaruhi oleh beberapa faktor berikut ini:

Pertama, disparitas pidana dimulai dari hukum itu sendiri. Dalam peraturan hukum di Indonesia (KUHP) tidak memuat pedoman pemberian pidana (straftoemetingsleiddraad) sebagai pedoman yang dibuat 
pembentuk undang-undang yang berisikan asas-asas yang perlu diperhatikan oleh hakim dalam menjatuhkan pidana dimana yang ada hanyalah aturan pemberian pidana (straftoemetingsregels), sehingga tidak ada standar pemidanaannya (substansi hukum). Khususnya dalam penelitian ini mengacu pada Undang-undang Nomor 5 Tahun 1997 tentang Psikotropika.

Kedua, di dalam hukum pidana positif Indonesia, hakim mempunyai kebebasan yang sangat luas untuk memilih jenis pidana (strafsoort) yang dikehendaki, sehubungan dengan penggunaan sistem alternatif di dalam pengancaman pidana di dalam undang-undang.

Ketiga, tentang besar kecilnya ukuran barang bukti yang saat itu ditemukan dalam penggeledahan atau penangkapan. Selain itu, hakim juga akan mempertimbangkan dari cara penemuan barang bukti tersebut, apakah penemuannya saat tertangkap tangan atau ditemukan melalui pencarian terlebih dahulu.

Keempat, menyangkut motif/niat dari terdakwa dalam melakukan kejahatan tersebut. Selanjutnya dihubungkan dengan tujuan atau hasil akhir dari kejahatan yang telah terdakwa lakukan.

b. Upaya yang dapat dilakukan untuk meminimalisir terjadinya disparitas pidana dapat dilakukan dengan mengefektifkan fungsi majelis hakim dengan menggunakan semua potensi yang ada pada diri hakim sendiri. Seperti mengadakan pelatihan dan seminar yang diikuti oleh semua subsistem peradilan pidana guna meraih persamaan visi dan misi terhadap peradilan pidana. Selain itu juga melalui pendekatan pendekatan untuk memperkecil disparitas (approach to minimize disparity) dengan menciptakan pedoman pemberian pidana, meningkatkan peranan pengadilan banding, seleksi dan latihan para hakim khususnya di Pengadilan Negeri untuk konsistensi kebijakan pemidanaan. Dalam kasus penyalahgunaan psikotropika diperlukan adanya pedoman putusan yang jelas untuk penjatuhan pidana yang disesuaikan dengan ukuran barang bukti dan pedoman putusan untuk mengukur berat ringannya putusan pidana yang disesuaikan dengan motif terdakwa dalam melakukan penyalahgunaan psikotropika.

\section{Saran}

Adapun saran yang dapat penulis kemukakan untuk memperkecil terjadinya disparitas pidana adalah perlunya menciptakan suatu pedoman pemberian pidana (statutory guidelines for sentencing) dalam hukum pidana di Indonesia. Hal ini guna memberikan kemungkinan bagi para hakim untuk memperhitungkan seluruh fakta dari kejadian-kejadian, seperti berat ringannya delik dan cara delik itu dilakukan, kejelasan ukuran alat bukti, serta keadaan pelaku saat perbuatan pidana itu dilakukan. 


\section{DAFTAR PUSTAKA}

\section{A. BUKU DAN MAKALAH}

Anwar, Yesmil dan Adang (2009). Sistem Peradilan Pidana. Bandung: Widya Padjajaran.

Arief, Barda Nawawi. (2011). Kapita Selekta Hukum Pidana tentang Sistem Peradilan Pidana Terpadu (Integrated Criminal Justice System). Semarang: Universitas Diponegoro.

Emadila, Rina, dkk (2014). Makalah Metode Penelitian Kualitatif dengan Pendekatan Deskriptif. Bukittinggi.

Harkrisnowo, Harkristuti (2003). Rekonstruksi Konsep Pemidanaan: Suatu Gugatan Terhadap Proses Legislasi dan Pemidanaan Di Indonesia, Orasi pada Upacara Pengukuhan Guru Besar Tetap dalam Ilmu Hukum Pidana Fakultas Hukum Universitas Indonesia. Jakarta. Universitas Indonesia.

Makarao, Moh.Taufik (2003). Tindak Pidana Narkotika. Jakarta. Ghalia Indonesia.

Mertokosumo, Sudikno dan A. Pitlo. 2013. Bab-Bab Tentang Penemuan Hukum. Yogyakarta: Citra Aditiya Bakti.

Muladi dan Arief, Barda Nawawi (2005). Teori-teori dan Kebijakan Pidana. Bandung. Alumni.

Rahayu, Yusti Probowati (2005). Dibalik Putusan Hakim Kajian Psikologi Hukum dalam Perkara Pidana. Surabaya: Srikandi.

Reksodiputro, Mardjono (2007). Hak Asasi Manusia Dalam Sistem Peradilan Pidana. Jakarta: Universitas Indonesia.

Sudarto (2007). Hukum dan Hukum Pidana. Bandung: Alumni.

\section{B. PERATURAN PERUNDANG-UNDANGAN}

Undang-Undang Nomor 5 Tahun 1997

Undang-Undang Nomor 4 Tahun 2004

Undang-Undang Nomor 48 Tahun 2009

Polda DIY. Berkas Laporan Kasus Narkoba. 2006. Yogyakarta. 